\title{
Refugee Camp
}

National Cancer Institute

\section{Source}

National Cancer Institute. Refugee Camp. NCI Thesaurus. Code C85867.

A temporary, often makeshift shelter for persons displaced by war, political oppression,

or for religious beliefs. 